\title{
Analysis Of Use Sea Sand as A Fine Aggregate Replacement To Strong Press Concrete
}

\author{
Fachrul Arya Sanjaya, Sapto Budy Wasono, Diah Ayu Restuti Wulandari \\ Department of Civil Engineering, Faculty of Engineering, Narotama University, Indonesia \\ *Corresponding author E-mail: aryafachrul9@gmail.com
}

Manuscript received 15 April 2021; revised 1 May 2021; accepted 15 June 2021. Date of publication 3 July 2021

\begin{abstract}
Concrete is a composite building material made from a combination of aggregate and cement. The limitation of concrete material, in this case, is a fine aggregate (river sand). The utilization of sea sand as an alternative to fine aggregate in the manufacture of concrete is motivated by the availability of sea sand in nature in very large quantities. This study aims to determine the comparison and how much the compressive strength of concrete produced when using sea sand. The test was carried out when the specimens were 7,14 , and 28 days old with the specimens used in this study were concrete cylinders with a diameter of $15 \mathrm{~cm}$ and a height of $30 \mathrm{~cm}$. The results showed that the use of sea sand as a substitute for fine aggregate showed an average compressive strength in 7 days of $18.86 \mathrm{MPa}$, an average compressive strength of 14 days of $25.52 \mathrm{MPa}$, an average compressive strength of 28 days of $29.00 \mathrm{MPa}$. Then for the average compressive strength value of the use of river sand in 7 days is $17.17 \mathrm{MPa}$, the average compressive strength of 14 days is $23.24 \mathrm{MPa}$, the average compressive strength of 28 days is $26.41 \mathrm{MPa}$.
\end{abstract}

Keywords: Concrete, Compressive Strength, Sea Sand, Fine Aggregate.

\section{Introduction}

Sea sand generally has the characteristics of fine and round granules, which are uniform and contain salts that are not beneficial for concrete, so many are advised not to be used in making concrete. Smooth and round granules and uniform gradation, can reduce adhesion and affect the strength and durability of concrete. However, people who live on the coast still use sea sand as one of the fine aggregates on concrete for reasons easy to obtain [1] [2].

Sea sand is a material used as a substitute for ordinary sand for a mixture of cement, fine or coarse aggregate and water, with the mixture when poured into a mold and then allowed to stand hard. By using sea sand, the most important thing is the compressive strength of the concrete [3]. Factors that influence the compressive strength of concrete consist of the quality of the material, cement water, aggregates, how to process it such as mixing, compaction, and age of the test. Concrete is a result of mixing cement, water, fine aggregate, and coarse aggregate. Aggregate is the most important concrete component, which functions as a filler in a concrete mixture [4] [5].

Looking at several kinds of natural materials that can be used for making concrete, substituting or mixing concrete making such as sea sand are often found in various regions, especially Indonesia. And to utilize sea sand which so far has not been much used so as a researcher wants to test how strong the compressive strength of concrete using sea sand.

This research is to provide information about the use of sea sand as a substitute for river sand and also to predict the strength of concrete, as well as new breakthroughs in the world of civil engineering that are still needed [6].

\section{Literature Review}

\subsection{Concrete}

Concrete (concrete) is the main construction material most widely used besides steel. Concrete is obtained by mixing cement, fine and coarse aggregates, and water by a certain ratio. If the mixture is mixed and poured into a mold and then left, a hardening process will occur. The hardening process occurs because of the continuous chemical reaction between water and cement [7] [8].

\subsection{Sea Sand Instead of Fine Aggregate}

Sea sand is sand taken from the shores of the beach, the shape of the grains are smooth and round due to friction with each other [9]. This sand is bad because it contains a lot of salt. This salt absorbs water content from the air and causes the sand to always be rather wet and cause volume expansion when used on buildings. However, sea sand can be used in concrete mixtures with special treatment, that is by washing it so that the salt content is reduced or lost. Quality characteristics of fine aggregate used as concrete structural components play 
an important role in determining the quality characteristics of concrete structures produced because fine aggregates fill most of the concrete volume. Sea sand as one type of fine aggregate material has availability in large quantities [10].

\subsection{Concrete Compressive Strength}

Concrete compressive strength is the magnitude of the broad unity load that causes the concrete test specimen to disintegrate when it is burdened with a certain compressive force, which is produced by a press machine [11]. Based on the compressive strength of concrete can be divided into several types which can be seen in Table 1

Table 1. Several types of concrete according to compressive strength

\begin{tabular}{ll}
\hline Concrete type & Compressive Strength (MPa) \\
\hline Simple concrete & Up to $10 \mathrm{Mpa}$ \\
Normal concrete & $15-30 \mathrm{Mpa}$ \\
Pre-tensioned concrete & $30-40 \mathrm{Mpa}$ \\
Concrete high compressive strength & $40-80 \mathrm{Mpa}$ \\
Concrete compressive strength is very high & $>80 \mathrm{Mpa}$ \\
\hline
\end{tabular}

To calculate the compressive strength of concrete, a formula can be used:

$f c^{t}=\frac{p}{A}$

Description:

$\mathrm{fc}^{\prime} \quad=$ Compressive strength

$\mathrm{P} \quad=$ maximum load $(\mathrm{kg})$

A $\quad=$ cross-sectional area of test specimens $\left(\mathrm{cm}^{2}\right)$

\section{Methods}

The method used in this study is experimental, an experiment that aims to investigate the compressive strength of concrete by using sea sand instead of fine aggregate. The specimens made in this experiment were concrete cylinders with a diameter of $15 \mathrm{~cm}$ and a height of $30 \mathrm{~cm}$. Compressive strength testing is performed after the concrete is 7,21 , and 28 days old.

\section{Result and Discussion}

\subsection{Aggregate Test Results}

1. SSD Fine Aggregate Specific Gravity

In testing this fine aggregate specific gravity obtained data as follows:

Table 2. Testing the SSD Fine Aggregate Specific Gravity

\begin{tabular}{cccc}
\hline Fine aggregate & Weight W (gram) & Volume $\Delta \mathrm{V}(\mathrm{ml})$ & $\begin{array}{c}\text { Specific gravity }=\frac{W}{\Delta \mathrm{V}} \\
(\text { gram / ml) }\end{array}$ \\
\hline \multirow{3}{*}{ River sand } & 100 & 74 & 1.35 \\
& 100 & 71 & 1,4 \\
& 100 & 69 & 1.45 \\
Sea sand & 100 & 67 & 1,4 \\
& 100 & 71 & 1.5 \\
& 100 & 69 & 1,4 \\
& Average $(\mathrm{gram} / \mathrm{ml})$ & & 1.45 \\
& & & \\
\hline
\end{tabular}

2. Testing of Fine Aggregate Water Content

In testing the fine aggregate moisture content obtained the following data:

Table 3. Testing of Fine Aggregate Water Content

\begin{tabular}{cccc}
\hline Fine aggregate & $\begin{array}{c}\text { Initial weight A } \\
\text { (grams) }\end{array}$ & $\begin{array}{c}\text { Dry Weight B } \\
(\text { gram })\end{array}$ & $\begin{array}{c}\text { Water content }=\frac{\mathbf{A}-\mathbf{B}}{\mathbf{B}} \times 100 \\
(\%)\end{array}$ \\
\hline \multirow{3}{*}{ River sand } & 100 & 96.39 & 3,750 \\
& 100 & 97.23 & 2,850 \\
& 100 & 95.75 & 4,440 \\
Sea sand & Average $(\%)$ & & 3,680 \\
& 100 & 97.80 & 2,250 \\
& 100 & 98.15 & 1,885 \\
& 100 & 98.50 & 1,520 \\
& Average $(\%)$ & & 1,885 \\
\hline
\end{tabular}

3. Testing of Fine Aggregate Mud Content

In testing the fine aggregate sludge levels the following data were obtained: 
Table 4. Testing of Fine Aggregate Mud Content

\begin{tabular}{ccccc}
\hline \multirow{2}{*}{ Fine aggregate } & $\begin{array}{c}\text { Weight of oven dry } \\
\text { aggregate A (gram) }\end{array}$ & $\begin{array}{c}\text { Weight of oven dry } \\
\text { aggregate after wash- } \\
\text { ing B (gram) }\end{array}$ & $\begin{array}{c}\text { Sludge levels } \\
\frac{\mathbf{A}-\mathbf{B}}{\mathbf{B}} \times 100 \\
(\%)\end{array}$ & $\begin{array}{c}\text { Specification } \\
<5 \%\end{array}$ \\
\hline \multirow{2}{*}{ River sand } & 96.39 & 93.25 & 3,367 & OK \\
& 97.23 & 93.45 & 4,044 & OK \\
& 95.75 & 92.55 & 3,457 & OK \\
Average $(\%)$ & & 3,622 & OK \\
& 97.80 & 95.50 & 2,408 & OK \\
& 98.15 & 96.75 & 1,447 & OK \\
& 98.50 & 96.70 & 1,861 & OK \\
\hline
\end{tabular}

4. Gross Rough Aggregate SSD

In this rough aggregate specific gravity test the following data are obtained:

Table 5. SSD Gross Aggregate Specific Gravity Testing

\begin{tabular}{cccc}
\hline \multirow{2}{*}{ Rough aggregate } & Weight W (gram) & Volume $\Delta V(\mathrm{ml})$ & $\begin{array}{c}\text { Specific gravity }=\frac{\mathrm{W}}{\Delta \mathrm{V}} \\
(\mathrm{gram} / \mathrm{ml})\end{array}$ \\
\hline \multirow{2}{*}{ Gravel } & 100 & 83 & 1.20 \\
& 100 & 70 & 1.42 \\
& 100 & 70 & 1.42 \\
& Average $(\mathrm{gram} / \mathrm{ml})$ & & 1.35 \\
\hline
\end{tabular}

5. Rough Aggregate Moisture Test

In testing the rough aggregate water content, the following data are obtained

Table 6. Testing of Coarse Aggregate Water Content

\begin{tabular}{cccc}
\hline Rough aggregate & $\begin{array}{c}\text { Initial weight A } \\
\text { (grams) }\end{array}$ & $\begin{array}{c}\text { Dry Weight B } \\
(\text { gram })\end{array}$ & $\begin{array}{c}\text { Water content }=\frac{\mathbf{A}-\mathbf{B}}{\mathbf{B}} \times 100 \\
(\%)\end{array}$ \\
\hline \multirow{2}{*}{ Gravel } & 200 & 198 & 1.01 \\
& 200 & 195 & 2.56 \\
& 200 & 197 & 1.52 \\
& Average $(\%)$ & 1.70 \\
\hline
\end{tabular}

6. Testing of Rough Aggregate Mud Content

In testing this coarse mud aggregate content obtained data as follows:

Table 7. Testing of Rough Aggregate Mud Content

\begin{tabular}{ccccc}
\hline Rough Aggregate & $\begin{array}{c}\text { Weight of oven dry } \\
\text { aggregate A (gram) }\end{array}$ & $\begin{array}{c}\text { Weight of oven dry } \\
\text { aggregate after wash- } \\
\text { ing B (gram) }\end{array}$ & $\begin{array}{c}\text { Sludge levels } \\
\frac{\mathbf{A}-\mathbf{B}}{\mathbf{B}} \times 100 \\
(\%)\end{array}$ & $\begin{array}{c}\text { Specification } \\
<5 \%\end{array}$ \\
\hline \multirow{2}{*}{ Gravel } & 198 & 196.5 & 0.763 & OK \\
& 195 & 194 & 1,025 & OK \\
& 197 & 195 & 0.767 & OK \\
\hline
\end{tabular}

\subsection{Concrete Test Results}

1. Compressive Strength Test Results

In compressive strength testing at the age of 3-day test specimens obtained the following data:

Table 8. Compressive Strength Test Results

\begin{tabular}{|c|c|c|c|c|c|c|}
\hline \multirow[t]{2}{*}{ No } & \multirow{2}{*}{$\begin{array}{c}\text { Test } \\
\text { Objects }\end{array}$} & \multirow[t]{2}{*}{ Age day } & \multicolumn{2}{|c|}{$\begin{array}{l}\text { Force Press } \\
\qquad(\mathrm{kN})\end{array}$} & \multicolumn{2}{|c|}{$\begin{array}{c}\text { Compressive Strength } \\
(\mathrm{N} / \mathrm{mm} 2)\end{array}$} \\
\hline & & & River Sand & Sea Sand & River Sand & Sea Sand \\
\hline 1 & I & 3 & 200 & 190 & 11.32 & 10.75 \\
\hline 2 & II & 3 & 185 & 205 & 10.47 & 11.60 \\
\hline 3 & III & 3 & 175 & 220 & 9.90 & 12.45 \\
\hline
\end{tabular}

2. Concrete Age Conversion Data Results

The results of compressive strength testing on the age of the test object 3 days later carried out the conversion of the concrete age to get the compressive strength data based on the variation in age to be achieved. Conversion data sought is in the form of 7-day, 14-day, and 28-day test specimens. From the conversion results we get the following data: 
Table 9. Test Object Conversion Results 3 Days to 7 Days

\begin{tabular}{|c|c|c|c|c|c|c|}
\hline \multirow[t]{2}{*}{ No } & \multirow{2}{*}{$\begin{array}{c}\text { Test } \\
\text { Objects }\end{array}$} & \multirow[t]{2}{*}{ Age day } & \multicolumn{2}{|c|}{$\begin{array}{l}\text { Force Press } \\
\qquad(\mathrm{kN})\end{array}$} & \multicolumn{2}{|c|}{$\begin{array}{c}\text { Compressive Strength } \\
\text { (N/mm2) }\end{array}$} \\
\hline & & & River Sand & Sea Sand & River Sand & Sea Sand \\
\hline 1 & I & 7 & 325 & 309 & 18.39 & 17.49 \\
\hline 2 & II & 7 & 301 & 333 & 17.01 & 18.84 \\
\hline 3 & III & 7 & 284 & 358 & 16.09 & 20.26 \\
\hline
\end{tabular}

Table 10. Test Object Conversion Results 3 Days to 14 Days

\begin{tabular}{|c|c|c|c|c|c|c|}
\hline \multirow[t]{2}{*}{ No } & \multirow{2}{*}{$\begin{array}{l}\text { Test } \\
\text { Objects }\end{array}$} & \multirow[t]{2}{*}{ Age day } & \multicolumn{2}{|c|}{$\begin{array}{l}\text { Force Press } \\
\qquad(\mathrm{kN})\end{array}$} & \multicolumn{2}{|c|}{$\begin{array}{c}\text { Compressive Strength } \\
(\mathrm{N} / \mathrm{mm} 2)\end{array}$} \\
\hline & & & River Sand & Sea Sand & River Sand & Sea Sand \\
\hline 1 & I & 14 & 440 & 418 & 24.90 & 23.65 \\
\hline 2 & II & 14 & 407 & 451 & 23.03 & 25.52 \\
\hline 3 & III & 14 & 385 & 484 & 21.79 & 27.39 \\
\hline
\end{tabular}

Table 11. Test Object Conversion Results 3 Days to 28 Days

\begin{tabular}{|c|c|c|c|c|c|c|}
\hline \multirow[t]{2}{*}{ No } & \multirow{2}{*}{$\begin{array}{c}\text { Test } \\
\text { Objects }\end{array}$} & \multirow[t]{2}{*}{ Age day } & \multicolumn{2}{|c|}{$\begin{array}{l}\text { Force Press } \\
\qquad(\mathrm{kN})\end{array}$} & \multicolumn{2}{|c|}{$\begin{array}{c}\text { Compressive Strength } \\
(\mathrm{N} / \mathrm{mm} 2)\end{array}$} \\
\hline & & & River Sand & Sea Sand & River Sand & Sea Sand \\
\hline 1 & I & 28 & 500 & 475 & 28.29 & 26.88 \\
\hline 2 & II & 28 & 463 & 513 & 26.17 & 29.00 \\
\hline 3 & III & 28 & 438 & 550 & 24.76 & 31.12 \\
\hline
\end{tabular}

3. Results of Average Compressive Strength by Age

From the compressive strength results that have been obtained, the average compressive strength of each age is as follows: Table 12. Results of Average Compressive Strength by Age

\begin{tabular}{cccc}
\hline \multirow{2}{*}{ No } & \multirow{2}{*}{ Age day } & \multicolumn{2}{c}{$\begin{array}{c}\text { Average Compressive Strength } \\
(\mathrm{N} / \mathrm{mm} 2)\end{array}$} \\
\cline { 4 - 4 } & 7 & River Sand & Sea Sand \\
& 14 & 17.17 & 18.86 \\
2 & 28 & 23.24 & 25.52 \\
3 & 26.41 & 29.00 \\
\hline
\end{tabular}

\subsection{Discussion}

1. Comparison of Concrete Compressive Strength

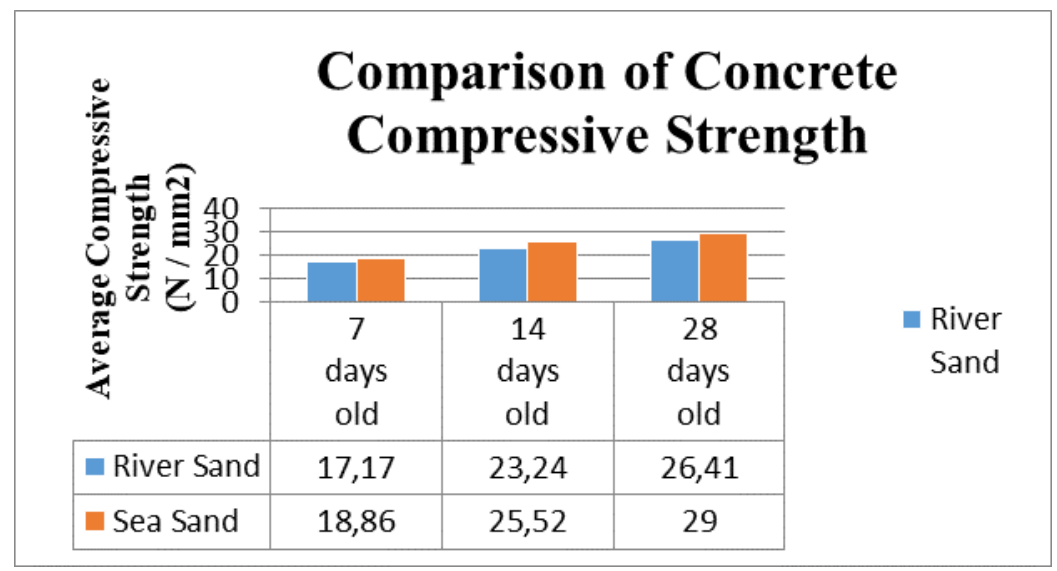

Fig 1. Comparison of Concrete Compressive Strength

Concrete compressive strength testing is done to see whether the concrete has a strength that meets planned requirements. In concrete cylinders using river sand at the age of 7 days, the average compressive strength of concrete is $17.17 \mathrm{MPa}$, age of 14 days the average compressive strength of concrete is $23.24 \mathrm{MPa}$ and the age of 28 the average compressive strength of concrete is 26.41 MPa. Concrete cylinders using sea sand at the age of 7 days the average compressive strength of concrete was $18.86 \mathrm{MPa}$, age of 14 days the average compressive strength of concrete was $25.52 \mathrm{Mpa}$, and the age of 28 days the compressive strength of concrete was $29.00 \mathrm{MPa}$.

The test data shows that the strength of concrete made using sea sand has an average compressive strength that is relatively higher than that of concrete made using river sand.

Based on the compressive strength of concrete can be divided into several types: 
Table 13. Some Types of Concrete According to its compressive strength

\begin{tabular}{ll} 
Concrete type & Compressive Strength (MPa) \\
Simple concrete & Up to $10 \mathrm{Mpa}$ \\
Normal concrete & $15-30 \mathrm{Mpa}$ \\
Pre-tensioned concrete & $30-40 \mathrm{Mpa}$ \\
Concrete high compressive strength & $40-80 \mathrm{Mpa}$ \\
Concrete compressive strength is very high & $>80 \mathrm{Mpa}$ \\
\hline
\end{tabular}

From the results of the concrete compressive strength test, the strength of the concrete ranges between 17-29 MPa. Judging from the table above, the concrete can be used for normal types of concrete.

2. Concrete Quality

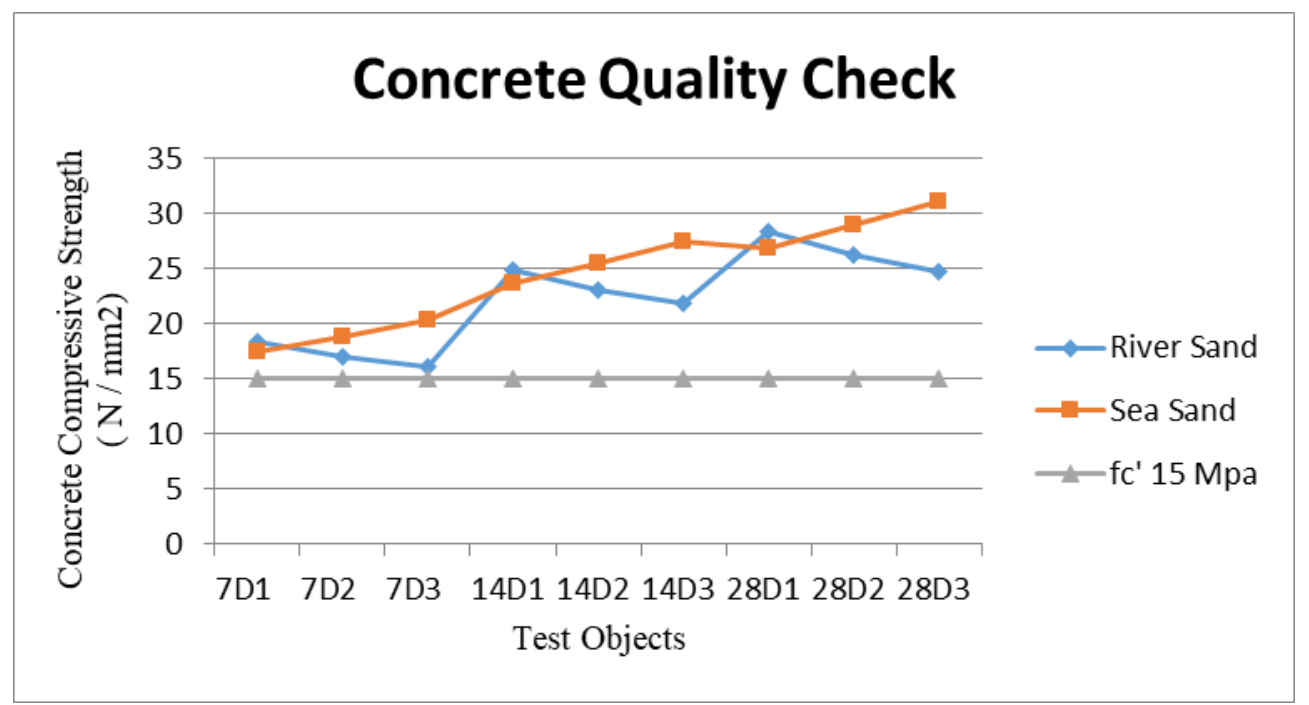

Fig 2. Concrete Quality Check

From the graph above, the quality of concrete is considered to meet the requirements (quality is achieved). The value of the compressive strength test results is based on variations in the age of 7 days, 14 days, and 28 days consisting of 3 specimens each, not less than the compressive strength of concrete required, namely fc ' $15 \mathrm{Mpa}$.

\section{Conclusion}

Based on the results of research and discussion on the use of sea sand as a substitute for fine aggregate against concrete compressive strength as well as a comparison of concrete compressive strength using sea sand and river sand can be drawn several conclusions as follows:

1. Sea sand can be used as a smooth aggregate substitute because the sea sand has a smooth and rounded texture which is great for concrete constituent materials. For a strong value of its own pace is greater than the use of river sand with a mixture of the same concrete quality.

2. The data value of the test results showed that the strength of concrete made by using sea sand has strong press averages which are relatively higher than in concrete made by using river sand.

3. The ratio of strong press concrete by using river sand at 7 days is $17.17 \mathrm{Mpa}, 14$ days at $23.24 \mathrm{Mpa}$, and age 28 for $26.41 \mathrm{MPa}$. While the strong value of concrete press by using sea sand at 7 days of $18.86 \mathrm{Mpa}, 14$ day age of $25.52 \mathrm{Mpa}$, and 28 day age of 29.00 MPa.

\section{References}

[1] P. Barbaro et al., "Safety Data Sheet," J. Am. Chem. Soc., 2009, doi: 10.1021/jm701266y.

[2] A. I. Abdullah, M. Dahlan, and T. Musa, "Uji Penerapan Metode Geolistrik Time-Lapse untuk Memonitoring Pergerakan Fluida Bawah Permukaan (Air Tanah) di Lokasi Sumur Produksi Air Tanah Warga Kelurahan Tondo Kota Palu," Gravitasi, 2017.

[3] "Kemampuan Mengikat Air oleh Tanah Pasir yang Diperlakukan dengan Tepung Rumput Laut Gracilaria verrucosa," Anat. Fisiol., 2007, doi: 10.14710/baf.v15i2.2570.

[4] N. Saidin, D. Singh, Z. A. Mohd Drus, and R. Hidayat, "Cultural Marker Identification for Web Application Design Targeted for Malaysian Multicultural Users,” Int. J. Adv. Sci. Eng. Inf. Technol., 2016, doi: 10.18517/ijaseit.6.6.1210.

[5] S. Wardi, Y. Sanada, M. Kita, J. Tanjung, and M. Maidiawati, "Common Structural Details and Deficiencies in Indonesian RC Buildings: Preliminary Report on Field Investigation in Padang City, West Sumatra," Int. J. Adv. Sci. Eng. Inf. Technol., 2018, doi: 10.18517/ijaseit.8.2.4207.

[6] M. Ayung Tama, M. I. Setiawan, and S. Budi Wasono, "Analysis Of The Performance East Circle Road Of Sidoarjo," Int. J. Eng. Sci. Inf. Technol., vol. 1, no. 2, 2021, doi: 10.52088/ijesty.v1i2.53.

[7] A. H. Ujang, A. R. Omar, I. A. Rani, A. Azmi, S. B. M. Kamal, and D. Abdullah, "Factors Influencing Consumer's Intention to use Self Service Technology in Tourism and Hospitality Industry," Int. Acad. Res. J. Bus. Technol., 2016.

[8] T. Drilled, M. Rooms, H. Concrete, C. Through, and I. Slump, "Standard Practice for Preparing and Testing Specimens from 
Shotcrete Test," Test, 2010.

[9] P. Vermeesch, C. R. Fenton, F. Kober, G. F. S. Wiggs, C. S. Bristow, and S. Xu, "Sand residence times of one million years in the Namib Sand Sea from cosmogenic nuclides," Nat. Geosci., 2010, doi: 10.1038/ngeo985.

[10] N. Sandra, K. Kawaai, and I. Ujike, "Influence of copper slag on corrosion behavior of horizontal steel bars in reinforced concrete column specimen due to Chloride-induced corrosion," Constr. Build. Mater., 2020, doi:

10.1016/j.conbuildmat.2020.119265.

[11] A. H. Ujang et al., "Factors Influencing Consumer's Intention to use Self Service Technology in Tourism and Hospitality Industry Article Information," Int. Acad. Res. J. Bus. Technol., 2016. 